(C) Dr W. Junk Publishers, Dordrecht - Printed in the Netherlands

\title{
Population dynamics of the ampharetid polychaete, Melinna palmata Grube, in Inner Galway Bay, west coast of Ireland*
}

\author{
Anthony Grehan \\ Department of Zoology, University College, Galway, Ireland
}

The ampharetid, Melinna palmata is a common member of the polychaete infauna occurring along the north shore of Galway Bay, (O'Connor, 1981). A high density population at one location was the focus for a two year study (April, 1983 to March, 1985). Five samples were taken each month with a modified $0.12 \mathrm{~m}^{2}$ van Veen grab (hinged $0.5 \mathrm{~mm}$ mesh doors fitted to the top to reduce bow wave). Samples were sieved on a $0.5 \mathrm{~mm}$ mesh and fixed in $10 \%$ buffered formalin. They were subsequently divided into $2 \mathrm{~mm}, 1 \mathrm{~mm}$ and $0.5 \mathrm{~mm}$ fractions. $M$. palmata were sorted from the $2 \mathrm{~mm}$ and $1 \mathrm{~mm}$ fractions and measured (10th setiger width) for construction of size frequency histograms. Monthly examination of coelomic contents from anaesthetised worms revealed the principal events of the reproductive cycle.

Melinna palmata in Galway Bay was shown to be polytelic with a breeding season extending from May to July. This is earlier than reported for the Breton coast (Retiere, 1979; Guillou \& Hily, 1983). Adult worms were gravid in May with spawning taking place until August when water temperatures were at their maxima, (approx. $17^{\circ} \mathrm{C}$ ). Simultaneously, proliferation of the following season's population of gametes commenced and increased

* This work was carried out within the framework of the COST 47 , core programme for the study of the 'target species', Melinna palmata Grube (Guillou \& Pearson, 1981). proportionally during the breeding period as spawning was completed. At the end of the spawning period, residual oocytes were reabsorbed and by October only new previtellogenic oocytes were present. Little change in oocyte diameter was apparent during the winter when water temperatures were at a minimum, (approx. $5^{\circ} \mathrm{C}$ ), but a rapid increase in oocyte diameter was observed in February coinciding with increasing water temperature.

Recruitment took place each year of the study as confirmed by additional samples taken in the postspawning period with a Muus sampler (quantitative meiofaunal samples from the top $2 \mathrm{~cm}$ of sediment with an area of $c a .160 \mathrm{~cm}^{2}$ ). At least three year classes could be discerned from the size frequency histograms.

\section{References}

Guillou, M. \& C. Hilly, 1983. Dynamics and biological cycle of a Melinna palmata (Ampharetidae) population during the recolonisation of a dredged area in the vicinity of the harbour of Brest (France). Marine Biology 74: 43-50.

Guillou, M. \& T. Pearson, 1982. Core programme: Annexe ID. Melinna palmata. COST 47 Newsletter. No. 2. National Board for Science and Technology, Dublin, $13 \mathrm{pp}$.

O'Connor, B., 1981. Benthic macrofaunal studies in the Galway Bay Area. Volume II. (Unpublished Ph.D. Thesis). University College, Galway. National University of Ireland, $292 \mathrm{pp}$.

Retiére, C., 1979. Contribution à la connaissance des peuplements benthiques du Golfe normanno-bréton. Thèse d'Etat, Université de Rennes, 421 pp. 